\title{
The Influence of Website Trust on Recommendation Adoption and Word-of-Mouth Communication: Study on TripAdvisor Website
}

\section{Shabrina Alhabsyi and Dien Mardhiyah}

Management Department, Faculty of Economics and Business, Universitas Airlangga

\section{Abstract}

The tourism industry has become one of the important economic sectors in Indonesia. The Ministry of Tourism states that, in recent years, Indonesia's tourism industry has always ranked fourth or fifth as an important foreign exchange earner in Indonesia. Seeing the opportunity, the tourism ministry is targeting an increase in the number of visitors by 2019. In achieving these targets, the government promotes an online

Corresponding Author: Shabrina Alhabsyi shabrinaalhabsyi@gmail.com

Received: 29 August 2018 Accepted: 18 September 2018 Published: 11 November 2018

Publishing services provided by Knowledge

(c) Shabrina Alhabsyi and Dien Mardhiyah. This article is distributed under the terms of the Creative Commons

Attribution License, which permits unrestricted use and redistribution provided that the original author and source are credited.

Selection and Peer-review under the responsibility of the ICOI-2018 Conference Committee.

\section{G OPEN ACCESS}

promotion strategy (e-marketing). Marketing activities are conducted through digital marketing, and the ministry is working with TripAdvisor to raise awareness of potential travelers. The interesting issue here is the discovery of fake reviews found on the TripAdvisor site. This study aims to investigate antecedents and consequences of website trust. This quantitative research used 200 respondents obtained through online questionnaires distributed to respondents who have used the TripAdvisor site. The results showed that propensity to trust, website reputation, and website quality had influence on website trust. Furthermore, website trust affected recommendation adoption and word-of-mouth.

Keywords: trust, reputation, quality, recommendation, website

\section{Introduction}

The tourism industry can be defined as a set of business fields that produce various types of products and services needed by those who travel. The tourism industry itself has become one of the important economic sectors in Indonesia. The official website of the Ministry of Tourism (www.kemenpar.go.id) mentions that, in recent years, Indonesia's tourism industry has always ranked fourth or fifth as the country's foreign exchange earner. The website www.indonesia-investments.com indicates that, up to October 2016, foreign tourists who visit Indonesia had reached 9,403,614. This shows an increase in foreign tourists compared to the previous period of 8,802,129 in 2013. 
Seeing the great opportunities provided by the tourism industry, the Government of Indonesia plans to optimize the role of the tourism industry in improving the Indonesian economy. The Government of Indonesia targets that, by 2019, the number of visitors will be increased to $20,000,000$ visits by foreign tourists (tourists) and 275,000,000 tourists visiting the archipelago (www.kemenpar.go.id). In order to achieve these targets, the government has increased its online promotional campaign (e-marketing) by following the trend of digital marketing (www.lombokinsider.com). The government is working with the TripAdvisor website to increase awareness of all tourists around the world about Indonesia's tourism (www.lombokinsider.com).

The interesting issue here is the discovery of fake reviews on the TripAdvisor website. This is known from the UK Advertising Standards Authority's (ASA) instruction to TripAdvisor to remove the "trust" claims on its website, as a result of several hotels complaining of fraudulent reviews (BBC, 2012). Even a report from Travolution revealed that hoteliers are often contacted by dubious organizations offering services to write positive reviews of their hotels on UGC websites like TripAdvisor for a monthly fee (Ayeh et al., 2013). It was feared that these issues could be a trigger of users' hesitation about the TripAdvisor website and questioning "trustworthiness" on UGC websites such as TripAdvisor, including the tourist attractions promoted on the website. As such, it is important for companies to pay particular attention to the "trusts", because it is a very important factor in e-commerce activities (Agag, 2016).

Based on the above explanations, this study aims to find the antecedents and the consequences of Website Trust on UGC (User Generated Content) TripAdvisor site. Variables in the research were chosen in relation to the many fraudulent phenomena that degrade consumer trust against UGC sites such as TripAdvisor.

\subsection{User generated content (UGC)/Consumer generated content (CGM)/User created content (UCC)}

UGC refers to types of dynamic media content available to the public and produced by end-users (www.marketing.co.id). Site owners make only necessary improvements or changes, while information updates and all interactions within the site come from the active participation of its users (www.marketing.co.id). There are various types of UGC, some are owned and filled by a single-user, such as blogs, and some are facilitated by a company and can be used by several users, such as the TripAdvisor site.

In e-commerce, UGC can serve as a new form of spreading information about a product or service that allows individuals to convey their ideas and opinions through 
the Internet and can be easily accessed by other Internet users (Dellarocas, 2003). The statistical data of Complete, Inc. show that nearly half of the information used to make trip planning and travel purchases use UGC sites. Moreover, almost a third of users claim that they find useful information and recommendations for their traveling from that site (Gretzel et al., 2007). Most UGC site users perceive that reviews about tourism products are more up-to-date, fun and trustworthy compared with information from travel service providers (Gretzel et al., 2008).

\subsection{Website trust}

Morgan and Hunt (1995) define trust as a person's belief in exchange that his partner is trustworthy and has integrity. Doney and Cannon (1997) define trust as the credibility and virtue felt by a person from a party who can be trusted. They also reveal that trust can develop depending on trustor expectations of the motives and behaviors of trustee. Bradach and Eccles (1989) see trust as a control mechanism that facilitates exchange relations characterized by uncertainty, vulnerability and dependency. These traits are reflected in the online environment where the buyer cannot verify the seller in detail, physically check the merchandise, or take the goods directly after payment (Chiu et al., 2010).

Trust in the online context, according to Kim et al. (2008), is conceptualized as an individual trust that online providers will fulfill their responsible to users. Wu et al. (2008) define trust as the desire of the user to believe that the seller is honest and reliable in online transactions, which further results in the user's belief that the seller is also a friendly person. Trust in an online store has been identified as a critical success factor for e-commerce activities (Hoffman et al., 1999; Jarvenpaa et al. 2000; Lee and Turban, 2001; Yoon, 2002, Flavian et al., 2006) and an important performance indicator on CGM sites, since trust can determine the willingness of users to receive information from CGM, and use that information in their purchasing decisions (Filleri, 2015).

\subsection{Antecedents of trust}

Propensity to Trust is defined as the tendency of one's trait to trust others in general (McKnight et al., 2002; Wu et al., 2010) and it is also as a measure of an individual's inclination to believe or not believe in a thing (Teo and Liu, 2007). Some people can easily believe in something even though the information obtained is still very limited, 
while others require more complete information (Salam et al., 2005). In online transactions where sellers and buyers do not meet physically, propensity to trust plays an important role because it reduces perceived risk to users (Humphrey and Schmitz, 1998; Mukherjee and Nath, 2007). Some studies show that propensity to trust has a positive effect on the establishment of online trust (Gefen, 2000; Teo and Liu, 2007; Beldad et al., 2010). The research results of Agag and El-Masry (2016) also mentioned that online travelers with high propensity to trust have more trust in online travel websites. Based on the above description, this research proposes the hypothesis as follows:

\section{H1: Propensity to Trust positively affects Website Trust.}

Website reputation is defined by Doney and Cannon (1997) as a user perception of the professionalism of the website, such as competent and honest. Reputation is also a form of signaling to users that the stated vendor is a trusted one (Shapiro, 1983). According to signaling theory, companies can take action and give cues in which there is information about vendor quality to users (Duncan and Moriarty, 1998; Rao et al., 1999; Ray et al., 2011). As one form of information about vendors, reputation not only shows past performance, but also shows that vendors are not involved in bad behavior, like cheats (Dawar and Parker, 1994; Grazioli and Jarvenpaa, 2000). Some studies have suggested that a positive reputation of a website may affect consumer trust, not only on websites, but also on online vendors (Chen, 2006; Teo and Liu, 2007).

\section{H2: Website Reputation positively affects Website Trust.}

Perceived Ease of Use is defined as the perception of a person that using a system does not require much effort (Davis, 1989). A periodic study by Bart et al. (2005) that examined the factors that influence user trust in a website found that easy-to-use websites which are easier for users to plan their trips, would be faster in gaining user trust. Websites that are easy to understand and use by consumers will reduce perceptions of perceived risk. Decreasing perceived risk of consumers makes trust increase. Some research results found that perceived ease of use is a determinant of consumer trust on online travel websites (Gefen et al., 2003; Bart et al., 2005; Chen, 2006; Flavian et al., 2006; Tung, Chang and Chou, 2008; Agag and El-Masry, 2016). Based on the description above, this research proposes the hypothesis as follows:

\section{H3: Perceived Ease of Use positively affects Website Trust.}

Perceived usefulness is defined as the perception of a person that, in using a particular system, it will improve the performance of his work (Davis, 1989). In the context of 
tourism and hospitality, perceived usefulness indicates that the use of the Internet can be useful to help get a pleasant trip for tourists (Luque-Martínez et al., 2007). Palvia (2009) proposed perceived usefulness as an antecedent of transaction intent based on a technology acceptance model (TAM). However, a business relationship that is developed based on trust is perceived to provide subjective assurance that the ecommerce company will behave in good faith and the results of the transaction will be fair and profitable. It increases the benefits of transacting on e-commerce websites, so users will want to use e-commerce facilities as they are considered more useful (Gefen et al., 2003). Based on the above description, this research proposes the hypothesis as follows:

\section{H4: Perceived Usefulness positively affects Website Trust.}

Website quality is someone's evaluation related to the website features, whether the feature has met the needs of users and reflects the benefits of the entire website (Chang and Chen, 2008). DeLone and McLean (2003) revealed that there are three aspects in website quality, namely: information quality, system quality and service quality. In Agag and El-Masry's (2016) research, quality information refers to the user's perception of the quality of information, privacy and security of an online travel website. System quality refers to the user's perception of the availability of options in the system, adaptability and response time of the system. While service quality refers to the user's perception of response, empathy and assurance provided by online travel websites. McKnight et al. (2004) also showed that the perception of website quality is positively related to beliefs and intentions to believe, because the use of a website can provide a sense of first-time vendor presence and reinforce first impressions. Several studies in e-commerce and tourism (Kim et al., 2011; Filieri, 2015) found a significant and positive relationship between website quality and user trust in the website. Based on the above description, this research proposes the hypothesis as follows:

\section{H5: Website Quality positively affects Website Trust.}

\subsection{Consequences of trust}

Recommendation Adoption is a process in which a person is intentionally involved in using information (Sussman and Siegal, 2003; Cheung et al., 2008). Senecal and Nantel (2004) note that product recommendations from other users are even more important to buyers for intangible product such as tourism, hotels and restaurants. According to Pan et al. (2007), recommendations from other users who have previous 
experience with tourism products are not only the most preferred information sources, but also the most influential ones for travel decision-making. According to Filieri (2015), in the context of CGM, a trustworthy website has capability of monitoring the truth of the reviews submitted by its users in the best interests of the user, thereby reducing the risk associated with fraudulent content. Therefore, when the user (CGM) believes that the information provided is trustworthy, the user's likelihood will likely adopt the advice given. This is in accordance with previous research findings conducted by Kim et al. (2011), Wang et al. (2015), Filleri (2015) and Agag et al. (2106). Based on the above description, this research proposes the hypothesis as follows:

\section{H6: Website Trust positively affects Recommendation Adoption.}

Word-of-mouth (WOM) is a form of communication about a product or service among a group of people who are not part of a company providing products or services (Silverman, 2001). Silverman's understanding of WOM highlights the importance of information sources, which are not from within the company. Filleri (2015) argues that, if a user trusts the CGM or WOM website from another party, they will then be more willing to talk to their friends and acquaintances about the website and the experience they get by using it. Due to reading through other user reviews, users can feel as if they have experienced the accommodation, restaurants or visiting tourist attractions featured on the website. Users who believe in a CGM site will feel that the information they received is true and reliable. This further encourages users to share with others that the CGM site can be used in connection with information retrieval. The more users who trust the CGM website, the more likely people tell to their friends and acquaintances the information from the website. Based on the above description, this research proposes the hypothesis as follows:

\section{H7: Website Trust positively affects word-of-mouth (WOM).}

\section{Research Methods}

\subsection{Participants, procedures and measurements}

This research used quantitative research approach with survey method. Data collection was done through the spread of online questionnaires given to those who ever use the TripAdvisor website. This study conducted a back translation of the measurements of the variables adopted from previous studies and made a questionnaire in the Indonesian language because the respondents used were Indonesians. Sampling was done by 
using non-probability sampling with purposive sampling technique to 200 responders (response rate 90\%). The indicators of variables in this research were adopted from previous research (Gefen et al., 2003; Teo and Liu, 2007; Cheung et al., 2008; Filieri, 2015; Agag and El Masry, 2016). The scale measurement used a 5-point Likert scale ( 1 = Strongly Disagree; 2 = Disagree; 3 = Neutral; 4 = Agree; 5 = Strongly Agree). The hypotheses in this study were tested with Structural Equation Modeling (SEM-AMOS).

\section{Results and Discussion}

\subsection{Demographic data and validity testing reliability measure tool}

Respondents used in this study amounted to 200 people. Samples were identified by respondents who had seen reviews online about a tourist spot on social media or the Internet and had used the TripAdvisor website. The majority of respondents were female (118 people, 59\%), The majority of respondents ages were 15-23 years old $(72 \%)$ and had senior high school level of last education (47\%) or as a student $(65 \%)$.

CFA test results on all variables in this research showed that all indicators of these variables had factor loading value $\geq 0.5$. This shows that the indicators on these variables can explain these variables well, so it can be said that these variables were valid and can be used for further analysis. Only five indicators of website quality were valid and only three indicators of recommendation adoption were valid.

The reliability test results indicated propensity to trust (0.932), website reputation (0.871), perceived ease of use (0.877), perceived usefulness (0.927), website quality (0.914), website trust (0.871), recommendation adoption (0.873) and word-of-mouth (0.942). From the data, it can be seen that the values of construct reliability of all variables are $\geq 0.70$. That is, these variables are reliable and can be used for research.

\section{Hypotheses Testing}

The results show that perceived ease of use and perceived usefulness have no significant effect on website trust. The perceived ease of use variable has $C R-1,196 \leq 1.96$ with $\mathrm{P} 0.232 \geq 0.05$ ( $\mathrm{H}_{3}$ is not supported). This is because perceived ease of use applies only to people who are new to technology or to new emerging technologies. The majority of respondents in this study were aged 15 - 23 years, where people in that age group were not new to technology. Thus, the perceived assessment of ease of use for them does not apply. Furthermore, perceived usefulness has $C R$ of $0.556 \leq 1.96$ and $P$ 
TABLE 1: Hypotheses Testing Results.

\begin{tabular}{|l|l|c|c|c|} 
& Path & C.R & P-Value & \\
\hline $\mathrm{H}_{1}$ & WEBTR $\leftarrow$ Propensity & 2,294 & 0,022 & Sig \\
\hline $\mathrm{H} 2$ & WEBTR $\leftarrow$ WEBREP & 2,762 & 0,006 & Sig \\
\hline $\mathrm{H} 3$ & WEBTR $\leftarrow$ PEASEOFUSE & $-1,196$ & 0,232 & Not Sig \\
\hline H4 & WEBTR $\leftarrow$ PUSEFL & 0,556 & 0,578 & Not Sig \\
\hline H5 & WEBTR $\leftarrow$ WEBQ & 4,267 & 0,000 & Sig \\
\hline H6 & RADOPT $\leftarrow$ WEBTR & 7,588 & 0,000 & Sig \\
\hline H7 & WMOUTH $\leftarrow$ WEBTR & 7,589 & 0,000 & Sig \\
\hline
\end{tabular}

$0.578 \geq 0.05$ ( $\mathrm{H}_{4}$ is not supported). This shows that perceived usefulness does not have a positive and significant effect on website trust. This is because perceived usefulness is more appropriate to be a consequence of trust, rather than as an antecedent of user trust in e-commerce companies. Where a trust-based transaction relationship can provide assurance to the consumer that the e-commerce company will behave well, and the results of the transaction will be fair and profitable, so as to increase the benefits in transacting with e-commerce companies (Gefen et al., 2003).

The results show that propensity to trust has CR $2.294 \geq 1,96$ with $\mathrm{P} 0.022 \leq 0,05$, indicating that propensity to trust has positive and significant effect on website trust (H1 supported). This is because someone with high propensity to trust tends to have a positive view on something and has a lower risk perception. This encourages someone to believe in something.

Testing influence of website reputation to website trust indicates that there is influence of website reputation to website trust. This is indicated by CR values of 2.762 $\geq 1.96$ and $\mathrm{P} 0.006 \leq 0.05$ ( $\mathrm{H} 2$ is supported). A reputable company can signal to its users that the company is honest and never engages in deceptive behavior. This can influence consumers' perceptions of the company, which will impact on consumers' willingness to believe in the site.

The test of $\mathrm{H}_{5}$ indicates that website quality has a positive effect on the website trust ( $\mathrm{H}_{5}$ is supported). This is shown with $\mathrm{CR}$ value $4.267 \geq 1.96$ and $\mathrm{P} 0.000 \leq 0.05$. The quality of a website can influence one's view (Ahn et al., 2007). Websites with good quality will be able to provide quality information, systems and good service as well. The third aspect will affect the willingness of consumers to believe in a website. Therefore, the features contained on the TripAdvisor site must be able to meet the needs of users and reflect the benefits of the TripAdvisor website compared to other websites in order for users to believe in the TripAdvisor site. 
Testing $\mathrm{H} 6$ also shows that website trust has a positive and significant effect on recommendation adoption with $C R$ values $7.588 \geq 1.96$ and $P 0.000 \leq 0.05$ ( $\mathrm{H} 6$ is supported). If the TripAdvisor site can fulfill its responsibility to provide honest and reliable information, users will feel that the TripAdvisor site is trustworthy and has integrity. Based on that, users who believe the TripAdvisor site will want to engage with the TripAdvisor site. In this case, the user will be willing to adopt the recommendations on the TripAdvisor website.

The hypothesis testing the influence of website trust on word-of-mouth shows CR value $7.589 \geq 1.96$ and $P 0.000 \leq 0.05$. This means that website trust has a positive and significant effect on word-of-mouth ( $\mathrm{H}_{7}$ is supported). If the user trusts the TripAdvisor site and all of the information, the user will be willing to tell their friends and acquaintances about the information they get from the TripAdvisor site as well as the experience they have gained by using the site.

\section{Discussion and Conclusion}

From the results of this study, we know the factors that affect consumer trust on a site. Furthermore, we know the impacts from consumer trust. From the data processing above, it is known that perceived ease of use and perceived usefulness variables do not have a positive and significant effect on website trust. And it can be seen also that website quality becomes the most significant factor among others which can influence consumer trust in a site. Therefore, marketers can understand how a website is qualified and optimize the quality of a given site.

\section{Implications, Limitations of Research, and Suggestions for Further Research}

Moreover, the results also show that users who believe in a site will be willing to adopt recommendations and disseminate positive information about the site. Both of these two things can benefit marketers. When a user already believes in the site and information provided, the user will be willing to adopt the recommendations on site in order to get a better trip. Users who have already adopted and are satisfied with the site will want to use the site and adopt recommendations in the future. Furthermore, when a site gains the trust of its users, they will want to spread positive information about the site. Companies who use that site will gain some benefits, such as the increasing popularity of the site among the users. In this way, marketers will be able 
to save significant money on advertising. In this case, their consumers will informally publish the site in their social environment, and the site name will spread rapidly among Internet users. Furthermore, marketers will be able to expand the market share it serves.

This research is also expected to provide benefits for new start-up companies to be more familiar with the needs of consumers on the Internet-related websites and to get examples and benefits from the TripAdvisor website, which is one of the 'teacher' websites.

\section{Research Limitations and Future Research}

This research does not escape shortcomings, so it cannot be said to be perfect. This study is limited to UGC TripAdvisor site as a research object, while there are other UGC sites that can be investigated further. So, for the future, authors are recommended to observe the website trust on other sites or compare the trust of users among some of these sites. Furthermore, the selection of respondents in this study is only based on those who have used the TripAdvisor site. It is expected that, in subsequent research, the selected respondents can be more specific, both from previous use of the site, age and other groupings in order to better understand the character of each group on UGC sites.

\section{References}

[1] Agag, G. M., \& El-Masry, A. A. (2016). Why Do Consumers Trust Online Travel Websites? Drivers and Outcomes of Consumer Trust toward Online Travel Websites. Journal of Travel Research, 47287516643185.https://doi.org/10.1177/ 0047287516643185

[2] Ahn, T., Ryu, S. and Han, I. (2007), "The impact of web quality and playfulness on user acceptance of online retailing", Information \& Management, Vol. 44 No. 3, pp. 263-75.

[3] Ayeh, J. K., Au, N., \& Law, R. (2013). Do we believe in TripAdvisor? Examining credibility perceptions and online travelers' attitude toward using user- generated content. Journal of Travel Research, 52(4), 437e452.

[4] Bart, Y., Shankar, V., Sultan, F., \& Urban, G. L. (2005). Are the drivers and role of online trust the same for all web sites and consumers? A large-scale exploratory empirical study. Journal of Marketing, 69(4), $133 \mathrm{e} 152$. 
[5] BBC (2012). "TripAdvisor Rebuked over Trust" Claims on Review Site." News Technology, BBC, February 1; 09:59 GMT. http://www.bbc.com/news/technology16823012 (accessed May 17, 2012).

[6] Chang, H. C., and S. W. Chen. (2008). "The Impact of Online Store Environment Cues on Purchase Intention: Trust and Perceived Risk as a Mediator." Online Inf. Rev 32 (6): 818-41.

[7] Chen, C. (2006). "Identifying Significant Factors Influencing Consumer Trust in an Online Travel Site." Information Technology and Tourism 8:197-214.

[8] Cheng, H. H., and S. W. Huang. (2013). "Exploring Antecedents and Consequence of Online Group-Buying Intention: An Extended Perspective on Theory of Planned Behavior." International Journal of Information Management 33:185-98.

[9] Cheung, C. M. K., Lee, M. K. O., \& Rabjhon, N. (2008). The impact of electronic wordof-mouth: the adoption of online opinions in online customer communities. Internet Research, 18(3), $229 e 247$.

[10] Chevalier, J. A., \& Mayzlin, D. (2006). The effect of word of mouth on sales: Online book reviews. Journal of Marketing Research, 43, 345-354.

[11] Chiou, J. S., \& Cheng, C. (2003). Should a company have message boards on its web sites?. Journal of Interactive Marketing, 17(3), 50-61.

[12] Chiu, C. M., H. Y. Huang, and Y. C. Hui. (2010). "Antecedents of Trust in Online Auctions." Electronic Commerce Research and Applications 9 (2): 148- 59.Cincinnati Ohio: South Western College Publishing.Corritore,

[13] Davis, F. D. (1989). "Perceived Usefulness, Perceived Ease of Use and User Acceptance of Information Technology." MIS Quarterly 13 (3): 319-40.

[14] Dawar, N., \& Parker, P. (1994). Marketing universals: Consumers" use of brand name, price, physical appearance, and retailer reputation as signals of product quality. Journal of Marketing, 58(2), 81-95.

[15] Dellarocas, C. (2003). The digitization of word of mouth: Promise and challenges of online feedback mechanisms. Management science,49(10), 1407- 1424.

[16] DeLone, W. H., and E. R. McLean. (2003). "The DeLone and McLean Model of Information Systems Success: A Ten-Year Update." Journal of Management Information Systems 19 (4): 9-30.

[17] Doney, P. M., and J. P. Cannon. (1997). "An Examination of the Nature of Trust in Buyer-Seller Relationships." Journal of Marketing 61 (2): 35-51.

[18] Duncan, T., \& Moriarty, S. (1998). A communication-based marketing model for managing relationships. Journal of Marketing, 62(2), 1-13. 
[19] Filieri, R. (2015). Why do travelers trust TripAdvisor? Antecedents of trust towards consumer-generated media and its influence on recommendation adoption and word of mouth. Tourism Management, 51, 174-185. https://doi.org/10.1016/j. tourman.2015.05.007

[20] Flavian, C., M. Guinalíu, and R. Gurrea. 2006. "The Role Played by Perceived Usability, Satisfaction and Consumer Trust on Website Loyalty." Information \& Management 43 (1): 1-14.

[21] Gefen, D., E. Karahanna, and D. W. Straub. (2003). "Trust and TAM in Online Shopping: An Integrated Model." MIS Quarterly 27 (1): 51-90.

[22] Grazioli, S., \& Jarvenpaa, S. (2000). Perils of internet fraud: An empirical investigation of deception and trust with experienced internet consumers. Systems and Humans, 30(3), 395-409.

[23] Gretzel, U. (2007). Online travel review study: Role \& impact of online travel reviews. College Station, TX: Laboratory for Intelligent Systems in Tourism, Texas A \& M University.

[24] Gretzel, U., \& Yoo, K. H. (2008). Use and impact of online travel reviews. Information and communication technologies in tourism 2008, 35-46.

[25] Hoffman, L. D., Novak, T. P., \& Peralta, M. (1999). Building consumer trust online. Communications of the ACM, 42(4), $80 e 85$.

[26] Jarvenpaa, S. L., N. Tractinsky, and M. Vitale. (2000). "Consumer Trust in an Internet Store." Information Technology and Management 1 (1/2): 45- 71.

[27] Jarvenpaa, S. L., Tractinsky, N., \& Saarinen, L. (1999). Consumer trust in an internet store: a cross-cultural validation. Journal of Computer-Mediated Communication, $5(2)$.

[28] KEMENPAR. (2016). Retrieved July 19, 2017, from http://www.kemenpar.go.id/asp/ detil.asp?id=3284 Kemenpar: Promosikan Pariwisata Indonesia dan NTB Melalui Digital Marketing

[29] Kemenpar Gandeng TripAdvisor Promosi Digital Pariwisata. (2016). Retrieved July 19, 2017, from http://traveling.bisnis.com/read/20160906/85/581735/kemenpargandeng-tripadvisor-promosi-digital-pariwisata

[30] Kim, M. J., N. Chung, and C. K. Lee. (2011). "The Effect of Perceived Trust on Electronic Commerce: Shopping Online for Tourism Products and Services in South Korea." Tourism Management 32 (2): 256-65.

[31] Lee, M. K., and E. Turban. (2006). "A Trust Model for Consumer Internet Shopping." International Journal of Electronic Commerce 6 (1): 75-91. 
[32] Morgan, R. M., \& Hunt, S. D. (1994). The commitment-trust theory of relationship marketing. The journal of marketing, 20-38.

[33] Palvia, P. (2009). "The Role of Trust in E-commerce Relational Exchange: A Unified Model." Information and Management 46 (4): 213-20.

[34] Pan, B., MacLaurin, T., \& Crotts, J. (2007). Travel blogs and the implications for destination marketing. Journal of Travel Research, 46(1), 35-45.

[35] Rao, A., Qu, L., \& Ruekert, R. (1999). Signaling unobservable product quality through a brand ally. Journal of Marketing Research, 36(2), 258- 268.

[36] Ray, S., Ow, T., \& Kim, S. S. (2011). Security assurance: How online service providers can influence security control perceptions and gain trust. Decision Sciences, 42(2), 391-412.

[37] Senecal, S., \& Nantel, J. (2004). The influence of online product recommendations on consumers' online choices. Journal of Retailing, 8o(2), $159 \mathrm{e} 169$.

[38] Shapiro, Carl (1983). "Premium for High Quality Products as Returns to Reputations," s," Quarterly Journal of Economics, 98 (November), $659-79$

[39] Silverman, G. (2001),"The power of word of mouth", Direct Marketing, Vol. 64, No. 5, pp.47-53.

[40] Sussman, S. W., \& Siegal, W. S. (2003). Informational influence in organizations: an integrated approach to knowledge adoption. Information Systems Research, 14(1), $47 e 65$.

[41] Teo, T. S., and J. Liu. (2007). "Consumer Trust in E-commerce in the United States, Singapore and China." Omega 35:22-38.

[42] Tung, F. C., S. C. Chang, and C. M. Chou. (2008). "An Extension of Trust and TAM Model with IDT in the Adoption of the Electronic Logistics Information System in HIS in the Medical Industry." International Journal of Medical Informatics 77:32435.

[43] Wu, Y. H., Chu, S. Y., \& Fang, W. C. (2008). An empirical study of trust and TAM: An example of online shopping. Journal of Information Management, 15(1), 123-152.

[44] Yoon, S. J. (2002). "The Antecedents and Consequences of Trust in Online- Purchase Decisions." Journal of Interactive Marketing 16 (2): 47-63. 